\title{
Perceptions of Vocational Counselors and Their Career Advice for Individuals Who Stutter
}

\author{
Heeyoung Park', Sohyun Park², Jin Park ${ }^{3}$ \\ 'Department of Communication Disorders, Ewha Womans University, Seoul, Korea \\ ${ }^{2}$ Department of Interdisciplinary Program of Communication Disorders, Chungnam University, Daejon, Korea \\ ${ }^{3}$ Department of Speech, Rehabilitation, and Counseling, Speech Rehabilitation Clinic Center, Catholic Kwandong University, Gangneung, Korea
}

Received: October 16, 2019 Revised: November 29, 2019

Accepted: December 16, 2019

\section{Correspondence:}

Jin Park, PhD

Department of Speech,

Rehabilitation, and Counseling

Speech Rehabilitation Clinic Center

Catholic Kwandong University,

24 Beomil-ro 579beon-gil,

Gangneung 25601, Korea

Tel: +82-33-649-7737

Fax: +82-33-649-7669

E-mail: gatorade70@cku.ac.kr
Purpose: This study aimed to evalvate perceptions of vocational counselors and their career advice for individuals who stutter. Methods: Forty-six vocational counselors were randomly assigned to two different stuttering conditions (mild and severe recordings, 23 per condition) and asked to listen to one of the recordings and to rate the speaker's suitability for 31 occupations, along with perceptions of the speaking demands and educational requirements for the occupations. The participants were also told to provide three pieces of career advice tailored to individuals who stutter. Results: Occupational suitability ratings were affected more by occupation-associated speaking demands than educational requirements, regardless of the severity of stuttering. The vocational counselors recommended occupations more with a lower speaking demand and emphasized efforts to overcome stuttering. Conclusion: These results indicate that vocational counselors tend to recommend less occupations with a high speaking demand to individuals who stutter but occupational advice and support to overcome employment difficulties should be provided for them.

Key Words: Career preparation, Occupational advice, Stuttering, Vocational counselor.

\section{INTRODUCTION}

의사소통장애란 개념, 구어, 비구어, 상징 체계를 수용하고 전 달, 처리하는 능력에 있어 질적인 손상을 의미하는 것으로 (ASHA, as cited in Paul \& Norbury, 2007), 아동의 언어 수용 및 표현 능력이 인지능력에 비해 떨어지는 아동 언어발달장애, 조음능력의 부족으로 의사소통에 상당한 문제를 보이는 조음 장애, 말 흐름 문제로 인해 의사소통에 상당한 제한을 보이는 말더듬, 성대결절이나 후두암으로 정상적인 목소리 산출의 어 려움을 보이는 음성장애, 그리고 실어증과 같은 성인기 언어장 애가 이에 포함된다. 의사소통장애를 겪고 있는 사람들은 단순 히 장애가 초래하는 신체적 또는 기질적 어려움뿐 아니라 장기 간에 걸쳐 일상 또는 사회생활에 상당한 제한성을 경험하게 되 면서 주로 삶의 질이 현저하게 저하되는 '이차적 장애'를 경험하 게 된다. 이러한 여러 의사소통장애 가운데 본 연구에서는 일 반인의 말더듬 성인에 대한 직업 선택 관련 인식과 가능한 직

(c) This is an Open Access article distributed under the terms of the Creative Commons Attribution Non-Commercial License (https://creativecommons.org/licenses/by-nc/4.0) which permits unrestricted non-commercial use, distribution, and reproduction in any medium, provided the original work is properly cited.
업적 조언에 대해 알아보고자 한다.

말더듬은 반복, 연장, 막힘과 같은 비유창성으로 말의 흐름 이 원활하지 않은 장애를 말한다(Lee, 2005; Van Riper, 1982). 이러한 구어(speech)상의 붕괴뿐 아니라 머리를 자꾸 뒤로 젖 힌다든지, 손으로 무릎을 친다든지, 눈을 자주 깜박거리는 것 등과 같은 부수행동이 동반되기도 한다. 더 나아가 여러 의사 소통 상황에서 말더듬으로 인해 잦은 실패를 경험하게 되면서 자신이 말을 해야 하는 상황 또는 말하기 어려운 상황, 예를 들 어 윗사람과 대화, 이성과 대화, 발표 상황, 전화 상황을 의도적 으로 회피하면서 이와 관련된 흥분, 긴장, 두려움, 부끄러움, 짜 증과 같은 감정 상태 등을 경험하게 된다. 결국 이러한 '실패자' 로서의 잦은 경험들이 '나는 말의 문제를 가지고 있는 사람'이 라는 자기 인식으로 발전하면서 개인 일상 및 사회생활에 매우 큰 부정적 영향을 미치게 된다.

말더듬이 한 개인을 위축케 하여 일상 및 사회생활에 전반적 으로 부정적인 영향을 미친다는 사실은 이미 상당한 사례나 실 험 연구를 통해 입증되었다(Craig et al., 2009; Logan \& O' Connor, 2012; Yaruss \& Quesal, 2004). 특히 말더듬 성인의 직업 선택 및 수행에 대한 연구들은 사회의 한 일원으로서 그 
들이 겪을 수 있는 사회적 참여 또는 역할의 제한성을 단적으 로 보여주고 있다(Gabel et al., 2004; Gabel et al., 2008; Hayhow et al., 2002; Hurst \& Cooper, 1983a; Hurst \& Cooper, 1983b; Klein \& Hood, 2004; Logan \& O'Connor, 2012). 이러 한 직업 관련 연구들은 크게 두 가지 유형으로 나누어 볼 수 있는데, 하나는 고용주, 직업상담사와 같은 직업 관련 일반인이 나 말더듬 성인 본인들을 대상으로 직업 추천 및 선택, 또는 수 행과 관련해 전반적인 인식 양상을 조사하는 것이다. 예를 들 어 Hurst \& Cooper(1983a)는 말을 더듬는 사람들을 고용하거 나 경험한 고용주 644명을 대상으로 말더듬 성인의 직업 추천 이나 수행에 대한 인식을 알아보았는데, 직업 추천과 관련해 응 답자의 $44 \%$ 는 비교적 말의 능력이 크게 요구되지 않는 직업(예 를 들어, 용접원)을 선택하는 것이 나을 것이라고 답하였다. 또 한 말더듬 문제가 직업을 수행함에 있어서 어려움의 원인이 될 것으로 응답한 사람이 $30 \%$ 였다. 그리고 응답자의 $85 \%$ 는 말더 듬이 취업 및 승진에 부정적인 영향을 미칠 수 있다고 답하였 다. 152 명의 직업상담사를 대상으로 한 이들의 후속연구(Hurst \& Cooper, 1983b)에서는 말더듬 문제가 취업에 상당한 방해가 될 수 있다고 응답한 사람이 $78 \%$ 를 차지하였다. 말더듬 성인 232명을 대상으로 한 Klein \& Hood(2004)에서는 응답자의 $40 \%$ 가 말더듬 문제가 없다면 다른 직업을 가졌을 것이라고 답 하였으며, $70 \%$ 는 자신들의 말더듬이 실제로 취업이나 승진에 부정적 영향을 미쳤다고 답하였다.

말더듬 성인의 직업 관련 연구의 또 다른 유형은 개별 직업 에 대한 추천 정도를 분석해 상대적으로 어떤 직업에 대한 추 천 정도가 높은지 그리고 이러한 추천에 영향을 미치는 유의한 요인들은 무엇인지를 조사하는 것이다(Gabel et al., 2004; Logan \& O’Connor, 2012). 구체적으로 385명의 대학생들을 대상 으로 한 Gabel et al.(2004)의 연구에서는 총 43개의 직업 목록 을 바탕으로 말더듬 성인에 대한 추천 정도를 조사하였다. 연 구 결과 20 개 직업(예를 들어, 판사, 검사, 언어치료사, 직업상담 사)에서 유의하게 낮은 추천 정도를 보였으며, 이는 말의 능력 이 말더듬 성인의 직업 추천에 유의하게 영향을 미치는 요인임 을 보여주었다. 116명의 대학생들을 대상으로 연구를 한 Logan \& O'Connor(2012)는 중도 정도에 차이가 있는(즉, 경도 말더듬 과 중도 말더듬) 실제 말더듬 성인의 음성 샘플을 들려주고 이 를 바탕으로 32 개의 직업 목록에 대해 직업 추천 정도를 조사 하였는데, 말더듬의 중도 정도에 상관없이, 즉, 경도 말더듬과 중도 말더듬 모두 말하기 요구량이 높은 직업(예를 들어, 대학 교수, 교사, 변호사, 아나운서)을 낮게 추천하였다. 아울러 이들 은 각 직업을 위해 필요한 교육 수준에 대한 견해, 전반적인 의 사소통능력, 발화를 통해 엿볼 수 있는 행동적 특성에 대한 인 식 정도 등과 같은 요인들이 말더듬 성인의 직업 추천에 유의
한 영향을 미치는지도 알아보았다. 연구 결과 직업 관련 말하기 요구량 정도뿐 아니라 직업 관련 교육 수준 정도, 의사소통능 력, 행동적 특성 모두 말더듬 성인의 직업 추천에 유의한 수준 에서 영향을 미치는 요인들임이 나타났다. 요컨대 전자의 연구 는 말더듬 성인에 일반적인 인식 양상 분석을 통해, 후자는 구 체적인 직업들에 대한 추천 정도와 관련 요인 분석을 통해 좀 더 실증적인 측면에서 말더듬 성인에 대한 직업 관련 역할이나 참여의 제한성을 보여주고 있다고 말할 수 있다.

이러한 문헌고찰을 바탕으로 본 연구의 동기를 기술하면 첫 째, 지금까지 말더듬 성인을 위한 직업 추천에 대한 연구들은 위에서 논의한 문헌들과 같이 주로 미국을 중심으로 한 해외에 서 행해져왔다. 말더듬뿐 아니라 말을 더듬는 사람에 대한 인 식에 있어, 그리고 이전 연구들에서(Gabel et al., 2004; Logan \& O’Connor, 2012) 제시한 직업 목록에 있어 사회적, 문화적 차이가 존재할 수 있기에 국내 상황에 좀 더 적합한 말더듬 성 인을 위한 직업 추천 연구가 필요하리라 본다. 둘째, 이전 연구 들은 주로 대학생들을 대상으로 연구를 진행하였다. 이와는 달 리 본 연구에서는 직업상담사를 대상으로 하여 말더듬 성인에 게 어떠한 직업을 추천하고 있는지 조사하였다. 직업상담사는 내담자의 개인적 특성을 고려하여 좀 더 적합한 직업의 종류 및 취업 준비를 위한 조언을 하여 내담자가 직업 선택과 관련 해 합리적인 의사결정을 하는 데 도움을 주는 취업 관련 상담 전문가라 할 수 있다. 그러므로 직업상담사를 대상으로 한 본 연구의 결과는 일반 대학생들과는 다른 좀 더 취업 관련 상담 전문가의 입장에서 말더듬 성인의 직업 관련 활동 및 참여에 대한 인식을 보여줄 수 있을 것이다. 마지막으로, 이전 연구들 은 말더듬 성인이 직업 추천 및 선택에 있어 상당한 제한성을 경험한다는 인식 연구들이 주를 이루고 있다. 반면에 말더듬 성인이 경험하는 진로 모색의 현실적 어려움 해결과 관련해 구 체적인 조언과 권고 사항에 대한 연구는 현재까지 거의 없다. 따 라서 본 연구에서는 말더듬 성인에 대한 직업상담사의 직업 추 천 양상과 정도뿐 아니라 아울러 이들을 위한 직업상담사의 실 제적인 직업 준비 관련 조언이나 권고 사항에 대한 연구를 진행 함으로써 단순한 문제 인식을 넘어 실제적으로 말더듬 성인에 게 도움이 될 수 있는 조언 내용에 대해서도 알아보고자 한다.

연구문제는 다음과 같다. 첫째, 중도 정도(즉, 경도 말더듬과 중도 말더듬)에 따라 직업상담사들의 말더듬 성인에 대한 직업 추천 정도가 달라지는가? 둘째, 직업과 관련된 말하기 요구량 과 교육 수준 정도는 각각 직업상담사의 직업 추천 정도와 유 의한 상관관계를 보이는가? 마지막으로, 말더듬 성인을 위해 직 업 추천 또는 준비와 관련해 직업상담사들이 제시하는 구체적 인 조언이나 권고 사항들은 무엇인가? 


\section{MATERIALS AND METHODS}

\section{연구 대상}

총 46명의 직업상담사들을 2가지 실험조건(즉, 경도 말더듬: 23명, 중도 말더듬: 23명)에 무작위로 배정하는 방식으로 실험 이 진행되었다. 대상자 모집은 다음과 같은 방식으로 이루어졌 다. 즉, 대학 내 취업정보센터, 시, 군, 구 소재의 고용정보센터 나 여성인력개발센터, 민간 취업지도기관, 한국직업상담사협회 나 한국직업상담사협동조합과 같은 유관기관을 통한 홍보나, 실험에 참가한 직업상담사들이 관심을 보일 만한 다른 직업상 담사들에게 알리는 방식으로 모집되었다.

실험 대상자는 다음과 같은 기준으로 선정하였다. 첫째는 한 국어를 모국어로 사용하며, 본 실험의 수행에 영향을 미칠 만 한 심리적, 정서적, 신경학적인 병력이 없으며, 시각 및 청각에 이상이 없으며, 이전에 언어나 말과 관련해 진단 또는 치료를 받은 경험이 없으며, 2급 이상 직업상담사 국가공인 자격증을 소지하여 최소 1 년 이상 실제 현장 업무 경험을 가지고 있어야 한다. 마지막으로 말더듬에 대한 전문지식이나 상담 경험이 없 는 대상자이어야 한다. 기본적으로 여러 사전 질의 문항을 통 해(예를 들어, "본인은 과거에 말, 언어 문제로 평가나 치료를 받 은 적이 있습니까?", "본인은 말더듬는 사람을 대상으로 직업 상담 관련 업무를 하신 적이 있습니까?”) 실험 대상자의 사전 지식이나 경험이 연구결과에 미치는 영향을 최소화하고자 하 였다. 연령 $(t(44)=1.594, p=0.118)$ 과 성비 $\left(\chi^{2}(1)=3.209, p=\right.$ $0.073)$, 그리고 평균 업무 경력 개월 수 $(t(44)=-0.091, p=$ 0.928)에 있어 두 집단 간 유의한 차이는 없었다. Figure 1에서 는 이러한 실험 대상자들의 기본 정보(즉, 평균연령, 성비, 평균 업무 개월 수)를 보여주고 있다.

\section{음성 샘플}

본 실험에서 사용된 음성 샘플은 말더듬 성인이 일정량의 구 절을 읽는 방식으로 생성되었다. 구체적으로 말하자면 남자 말 더듬 성인(33세)으로 하여금 '가을 문단'(Kim, 1996)을 말더듬 의 중도 정도와 관련해 2 가지 버전(즉, 경도 말더듬과 중도 말 더듬)으로 읽도록 하였다. 기본적으로 두 음성 샘플은 '의도적 말더듬(Van Riper, 1982) 방식으로 생성하였다. 음성 샘플 생성 에 참여한 말더듬 성인은 파라다이스 유창성검사 II (ParadiseFluency Assessment-II) (Shim et al., 2010)를 통한 평가 결과, 약함 정도의 중증도(백분위 점수: 21 30\%ile)에 해당되었다. 사례 질문지를 통한 보고에 따르면 말더듬은 6세 정도 시작되 었으며, 주요 말더듬 행동으로는 막힘과 반복이라고 하였다. 실 제 진단검사 시에는 막힘과 반복뿐 아니라 연장도 관측되었다. 평가는 수년간 유창성장애 진단 및 치료 경험을 가지고 있는 1

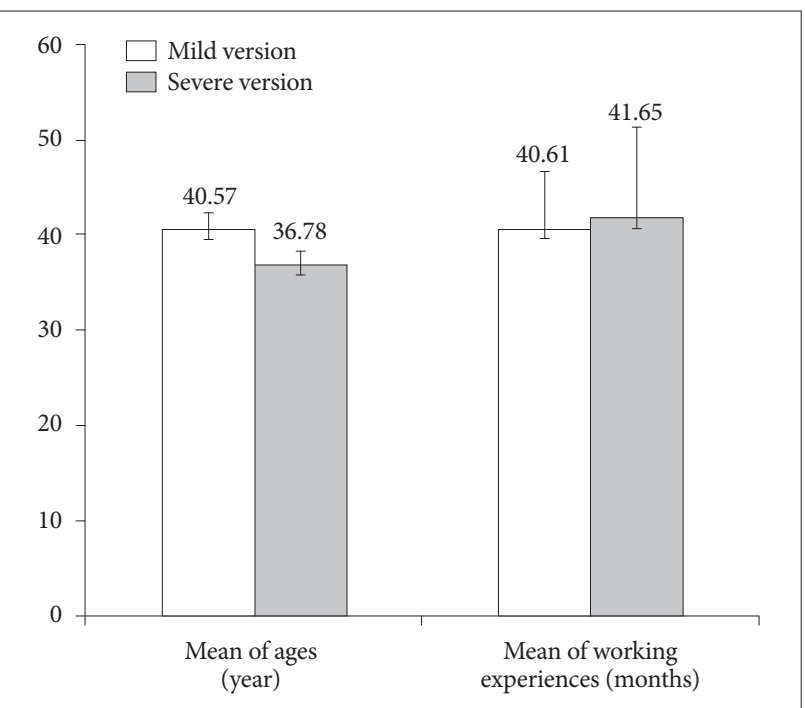

Figure 1. Characteristics of participants (means and standard errors of age and working experiences).

급 언어재활사가 실시하였다. 본 연구는 구어(speech)에서 나타 나는 말더듬 이외의 다른 변수들이, 예를 들어 말더듬 성인의 외모, 얼굴 표정, 손이나 몸동작과 같은 시각적 인상 등이 실험 결과에 미칠 수 있는 영향을 고려해 음성 샘플만을 사용하였다. 또한 음의 고저, 음색, 억양 등의 개인적 차이를 고려해 서로 다 른 두 사람이 아닌 동일한 화자의 음성 샘플을 녹음하여 진행 하였다. 음성 샘플은 ECM-PC60 (Sony, Shanghai, China) 마이 크와 X-FI Surround 5.1 USB (Creative, Hong Kong, China) 사운드 블라스터를 사용하여 방음 처리된 대학 소재 음성실험 실에서 녹음하였다. 녹음한 음성 샘플의 중증도와 관련해서는 첫째, 말더듬 빈도는 경도 말더듬은 15 회(4.06\%), 그리고 중도 말더듬은 78회(21.1\%)였다. 이 두 말더듬은 말더듬 중증도 검 사(Stuttering Severity Instrument-3) (Riley, 1994)의 읽기과 제 점수표를 기준으로 할 때 각각 5점과 9점에 해당된다. 둘째, 말더듬 지속시간을 측정한 결과 경도 말더듬은 0.98 초, 중도 말더듬은 3.15초로 나타났다. 이는 말더듬 중증도 검사의 말더 듬 지속시간 점수표를 기준으로 할 때 각각 4점과 10점에 해당 된다. 셋째, 전반적 말속도(비유창함과 심을 포함한 초당 발화 음절 수)에 있어 경도 말더듬은 3.51 , 중도 말더듬은 2.30이었 다. 이는 말더듬이나 발화 내 상대적인 긴 쉼 등이 잦아지면서 중도 말더듬에서 전반적 말속도가 상대적으로 더 느려지는 이 유로 해석될 수 있다. 이런 의미에서 결국 느린 전반적 말속도 는 말더듬의 중증도를 인지하는 데 중요한 또 하나의 변수라 할 수 있다. 마지막으로, 두 말더듬 모두 막힘이 가장 많았고, 그 다음이 반복, 이후 연장 순이었고 이는 말더듬 성인의 전형 적인 말더듬 유형의 출현 빈도와 일치하였다(Jeon \& Jeon, 2015). 두 음성 샘플의 말더듬 빈도(비율)상의 일치도 검증을 위 
해 본 실험의 목적을 인지하지 않고 있으며 수년간 말더듬의 임 상경험을 가지고 있는 2 명의 1 급 언어재활사가 참여하여 원래 제시한 말더듬 빈도(경도 말더듬 15회, 중도 말더듬 78회)와의 일치율을 측정하였다. 측정 결과 경도 말더듬에서는 각각 $100 \%, 93.33 \%$, 중도 말더듬에서는 $97.43 \%, 94.87 \%$ 의 일치율을 보였다.

\section{측정 도구}

\section{직업 목록 선정}

한국직업전망서(Korea Employment Information Service, 2015)에 기재된 총 191개 직업 목록 가운데 비교적 일상생활에 서 자주 접해 좀 더 친숙한 88개의 직업을 선별하였다. 이후 대 학생 33명을 대상으로 개별 직업에 대한 직업 관련 교육 수준 정도(즉, 각 직업을 위해 필요하다고 생각하는 교육 수준 정도) 와 말하기 요구량 정도(즉, 각 직업을 수행 시에 말하기가 차지 하는 중요성 정도)에 대한 설문조사('매우 낮음'의 1점에서 '매 우 높음의 5점까지)를 실시하였다. 최종적으로 평균 차이는 크 고 표준편차는 작은 31 개의 직업 목록을 선정하였다. 모든 직업 들은 다시 직업 관련 교육 수준 정도와 말하기 요구량 정도 점 수의 각 평균값을 기준으로 4 개의 직업군으로 나누었으며 $\mathrm{Ta}-$ ble 1 에서 각 직업군별 직업 목록을 제시하였다.

\section{평정 척도}

본 연구에서는 세 가지 척도를 측정하였다. 구체적으로 각 직 업을 위해 필요하다고 생각되는 교육 수준에 대한 정도를 평정 하는 '교육 수준 인식 척도', 특정 직업에 대한 말하기 요구량 정도를 평정하는 '말하기 요구량 인식 척도'와 특정 직업에 대 한 추천 정도를 평정하는 '직업 추천 척도'이다. 모든 평정 척도 는 5점 척도(1점은 '매우 낮음, 5점은 '매우 높음)로 구성되어
있으며, 직업 관련 교육 수준 척도와 말하기 요구량 척도는 Logan \& O’Connor(2012)에서 사용한 척도를, 직업 조언 척도 는 Gabel et al.(2004)에서 사용한 척도를 수정, 개발하였다. 각 평정 척도의 문항 내적 일관성 신뢰도(Cronbach's $\alpha$ )를 측정한 결과 직업 관련 교육 수준 인식 척도는 0.878 , 직업 관련 말하 기 요구량 인식 척도는 0.870 , 직업 추천 척도는 0.914 로 매우 높게 나타났다. 더불어 실험에 참가한 직업상담사들을 대상으 로 말더듬 성인을 위해 직업 추천 및 준비와 관련해 3가지 조언 을 기술하도록 하였다(“말을 더듬는 사람에 대해 직업 추천 및 준비와 관련해 조언을 해주신다면 무엇이 있습니까? 구체적으 로 3가지 조언을 기술해 주십시오.”).

\section{연구 절차}

연구 대상자에게 배부한 설문지를 통해 자격증 유무와 급수, 연령, 성별, 경력, 교육 정도와 같은 기본 정보를 조사하였다. 또 한 본인의 말더듬력과 말더듬 관련 경험 유무와 같은 말더듬 관련 정보도 조사하였다. 또한 연구 대상자에게 총 31 개 직업을 대상으로 교육 수준 인식 척도와 말하기 요구량 인식 척도를 작성하게 하였다. 기본적으로 듣게 될 음성 샘플의 영향을 배 제하기 위해 음성 샘플을 듣기 전에 직업 관련 교육 수준 인식 척도와 말하기 요구량 인식 척도를 작성하도록 하였다.

이후 음성 샘플을 듣고 제시된 해당 질문지(비유창성 평가 기록지, 직업 조언 척도)에 답하도록 하였다. 음성 샘플을 듣기 전에 다음의 지시 사항을 제공하였다. "당신은 이제 녹음된 음 성샘플을 듣게 될 것입니다. 음성 샘플을 들으면서 말 유창성이 깨어지거나, 부드러운 말의 흐름이 아닌 것처럼 들리는 부분에 동그라미나 빗금으로 표시해 주십시오. 이때 말하는 사람의 음 의 높낮이, 운율, 어조에 신경 쓰지 마시고 오직 비유창성에만 주의를 기울여 들어 주십시오. 음성 샘플은 총 3 번 듣게 되며 질문지에 표시된 사항은 매번 수정할 수 있습니다." 음성 샘플

Table 1. List of occupations classified by occupational educational requirements and speaking demands

\begin{tabular}{|c|c|c|}
\hline Classification & Definition & Occupation list \\
\hline $\begin{array}{l}\text { Occupational class I } \\
(\mathrm{n}=9)\end{array}$ & $\begin{array}{l}\text { Occupational class with low levels of both } \\
\text { educational requirements and speaking } \\
\text { demands }\end{array}$ & $\begin{array}{l}\text { Pet hair designer, fishery worker, truck driver, mail carrier, } \\
\text { janitor, wall paper specialist, welding specialist, car mechanic, } \\
\text { entertainment manager }\end{array}$ \\
\hline $\begin{array}{l}\text { Occupational class II } \\
(\mathrm{n}=7)\end{array}$ & $\begin{array}{l}\text { Occupational class with low level of } \\
\text { educational requirements but high level } \\
\text { of speaking demands }\end{array}$ & $\begin{array}{l}\text { Insurance clerk or manager, public relations assistant, sports } \\
\text { or recreational instructor, actor, matchmaker or wedding } \\
\text { planner, telemarketing salesman, receptionist (or usher) }\end{array}$ \\
\hline $\begin{array}{l}\text { Occupational class III } \\
(\mathrm{n}=7)\end{array}$ & $\begin{array}{l}\text { Occupational class with high level of } \\
\text { educational requirements but low level } \\
\text { of speaking demands }\end{array}$ & $\begin{array}{l}\text { Airplane pilot, land surveyor, mate, network system engineer, } \\
\text { software engineer, architect, engineer }\end{array}$ \\
\hline $\begin{array}{l}\text { Occupational class IV } \\
(\mathrm{n}=8)\end{array}$ & $\begin{array}{l}\text { Occupational class with high levels of both } \\
\text { educational requirements and speaking } \\
\text { demands }\end{array}$ & $\begin{array}{l}\text { Interpreter, CEO, elementary-school teacher, lawyer, announcer, } \\
\text { stock or foreign exchange dealer, college professor, counselor }\end{array}$ \\
\hline
\end{tabular}


은 LifeChat, LX-3000 (Microsoft Cooperation, Redmond, WA, $\mathrm{USA}$ ) 헤드셋을 착용한 후 $75 \mathrm{~dB} \mathrm{SPL}$ 이내의 적절한 듣기 수 준(Rami et al., 2005)에서 제시하였다. 마지막으로 직업상담사 의 말더듬 성인을 위한 직업 추천 및 준비와 관련해 3 가지 구체 적인 조언을 기술하도록 하였다.

\section{통계 분석}

비유창성 빈도에 있어 2개의 실험조건 간(즉, 경도 말더듬과 중도 말더듬) 차이를 알아보기 위해 독립표본 $t$ 검정(independent $t$-test)을 실시하였다. 실험조건에 따른 교육 수준 정도와 말하기 요구량에 차이가 있는지 알아보기 위해 다변량분산분 석(multivariate analysis of variance, MANOVA)을, 실험조건 과 직업군에 따른 직업 추천 정도를 비교하기 위해 혼합요인분 산분석(mixed ANOVA)을 실시하였다. 또한 직업 추천 정도와 직업 관련 말하기 요구량 인식 정도와 교육 수준 인식 정도 간 의 상관관계를 분석하기 위해 Spearman 상관검정을 실시하였 다. 이러한 통계 분석을 위해 4 개의 직업군에 속한 모든 개별 직업들의 추천 점수, 직업 관련 말하기 요구량 인식 점수, 그리 고 교육 인식 점수의 평균값을 종속변수로 사용하였다. 효과크 기는 다변량분산분석과 혼합요인분산분석에서 부분에타제곱 $\left(\eta p^{2}\right)$ 값과 Cohen's d 값을, 상관 분석에서 rho 값을 통해 측정 하였다. 통계 분석은 SPSS v. 22 (IBM Corp., Armonk, NY, USA) 프로그램을 사용하였다.

직업상담사들이 제공한 조언은 질적 분석 방법인 연속적 비 교법에 의해 분석하였다. 구체적으로 먼저 연구자들이 독립적 으로 조언의 내용을 읽고 귀납적 분석을 통해 대표하는 핵심어 를 도출, 부호화 작업을 실시하였다. 이후 새로운 조언들 간의 연속적인 비교를 통해 범주와 주제를 도출하였다(Morgan \& Krueger, 2004). 부호집을 작성한 후 각 부호의 정의에 대해 함 께 논의하고 정의하여 최종 부호집을 정리하였다. 부호집은 가 장 많이 언급된 조언에 대한 부호 순으로 정리한 이후, 각 부호 에 해당하는 조언들을 기록하고 최종적으로 가장 대표적인 조 언을 선발하여 결과에 제시하였다. 모든 부호화 작업에 세 명의 연구자가 참여함으로써 질적 분석 결과의 타당도와 신뢰도를 높이고자 노력하였다.

\section{RESULTS}

\section{비유창성 빈도}

2개의 실험조건 간 비유창성 빈도의 차이를 살펴보기 위하 여 독립표본 $t$ 검정을 실시한 결과 실험조건 간에 유의미한 차 이가 나타났다 $(t(44)=-4.530, p<0.001)$. 이는 경도 말더듬과 중도 말더듬 간 실험 대상자가 지각하는 비유창성의 빈도에 있
어 유의한 차이가 나타났음을 보여주는 결과이다. 경도 말더듬 에서는 비유창성의 평균값 $[\mathrm{M}=16.00$, standard deviation $(\mathrm{SD})=3.50]$ 이 실제 횟수(15회)와 차이가 크지 않았으나 중도 말더듬 $(\mathrm{M}=32.65, \mathrm{SD}=17.70)$ 에서는 실제 횟수(78회)와 비교 적 큰 차이를 보였다. 이는 말더듬 평가에 익숙하지 않은 직업 상담사가 상대적으로 말더듬 빈도가 더 잦은 중도 말더듬의 빈 도를 측정하고 파악하는 것이 상대적으로 더 어렵기 때문으로 판단된다. 또한 막힘의 경우, 비교적 짧은 그리고 단순한 시각 적 긴장만으로 나타날 수 있기에 음성 샘플만을 가지고 정확한 파악이 어려울 수 있다. Figure 2는 비유창성 빈도에 대한 실험 조건 간 차이를 보여주고 있다.

\section{직업 관련 교육 수준과 말하기 요구량 정도}

다변량분산분석(MANOVA) 결과 실험조건 간 직업 관련 교 육 수준[Wilk's Lambda $=0.198, \mathrm{~F}(31.000,14.000)=1.826, p$ $\left.=0.116, \eta \mathrm{p}^{2}=0.802\right]$ 과 말하기 요구량 정도[Wilk's Lambda = $\left.0.303, \mathrm{~F}(31.000,14.000)=1.039, p=0.490, \eta p^{2}=0.697\right]$ 에 있 어 모두 유의한 차이가 나타나지 않았다. 이는 말더듬 음성샘 플을 들려주기 전에 각각의 직업에 관련해 필요한 교육 수준과 말하기 요구량을 평정하게 하였으므로 경도와 중도 말더듬 평 가집단 간 차이가 없는 것으로 해석된다. 따라서 전체 실험 대 상자(46명)를 통합해 직업을 위해 필요한 교육 수준과 요구되 는 말하기 정도를 기준으로 4개의 직업군(두 가지 모두 낮은 직 업군, 교육 수준은 낮지만 말하기 요구량 정도는 높은 직업군, 교육 수준은 높지만 말하기 요구량 정도는 낮은 직업군, 두 가 지 모두 높은 직업군)으로 분류하였다. 이는 대학생들을 대상

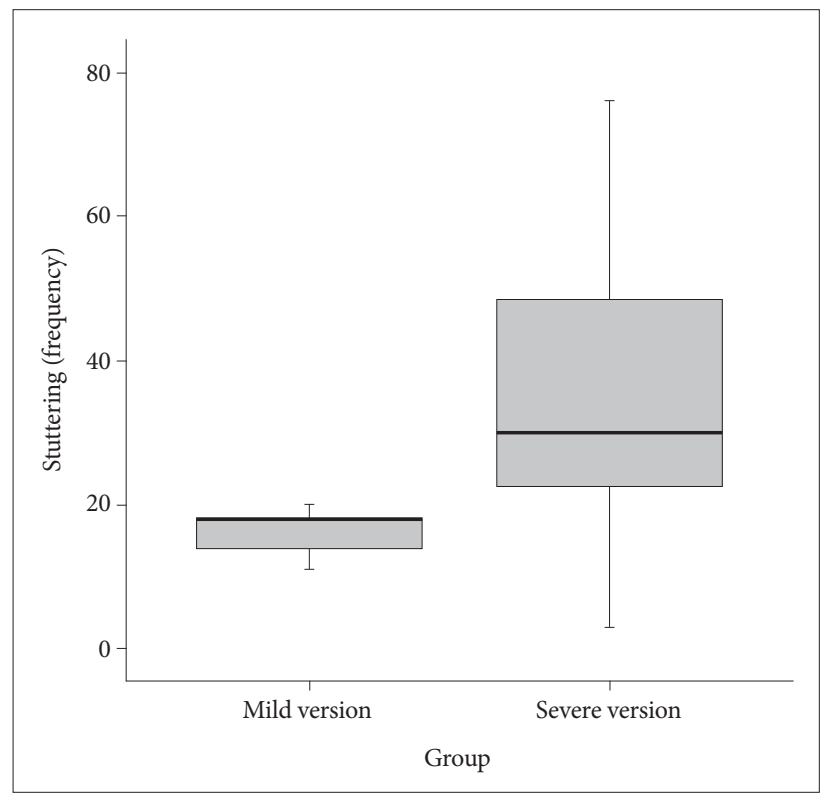

Figure 2. Disfluency frequency across the experimental conditions. 
으로 한 4개의 직업군 분류(Table 1)와 동일한 결과로 나타났 다. Figure 3 은 4개의 직업군을 산점도로 표시한 것이다. X축과 Y축은 필요한 교육 수준과 말하기 요구량 정도의 평균을 의미 한다. 각 축의 참조선은 31 개 직업들의 전체 평균값(교육 수준 = 3.46 , 말하기 요구량 $=3.43)$ 을 보여준다.

\section{직업 추천 정도}

실험조건과 직업 관련 교육 수준과 말하기 요구량을 바탕으 로 한 4개의 직업군에 따른 직업 추천 정도와 양상을 알아보기 위해 4개의 직업군을 개체 내 요인으로, 2 개의 실험조건을 개 체 간 요인으로 혼합요인분산분석을 실시하였다. 분석결과 직 업군 간에는 $\left[\mathrm{F}(2.483,109.231)=268.208, p<0.001, \eta p^{2}=\right.$ $0.859]$ 유의미한 차이가 나타난 반면, 실험조건 간에서는 $[\mathrm{F}(1$, 44) $\left.=2.765, p=0.103, \eta p^{2}=0.059\right]$ 유의미한 차이가 나타나지 않았다. 대응표본검정(pairwise comparison)을 통한 사후검정 결과, 직업과 관련된 말하기 요구량과 교육 수준 정도에 따라 분류된 4가지 직업군들(1: 교육하 말하기 하, 2: 교육하 말하기

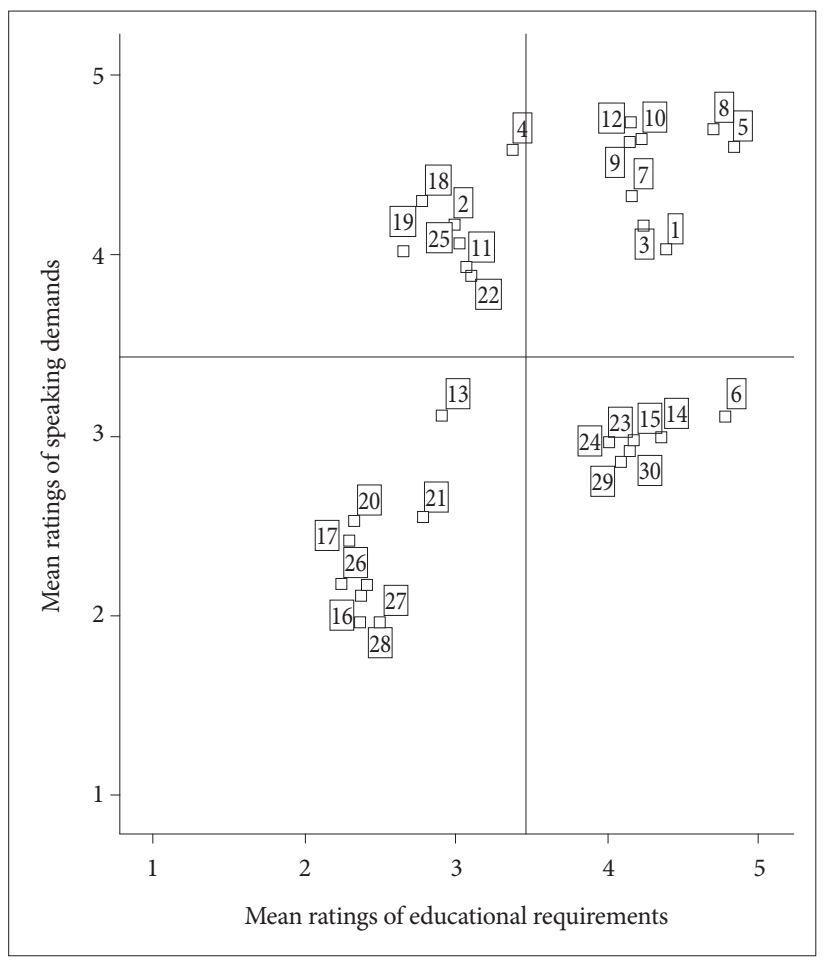

Figure 3. Mean ratings of speaking demands and educational requirements associated with the 31 occupations. 1: CEO, 2: receptionist (or usher), 3: stock or foreign exchange dealer, 4: insurance clerk or manager, 5: college professor, 6: engineer, 7: elementaryschool teacher, 8: lawyer, 9: counselor, 10: interpreter, 11: actor, 12: announcer, 13: entertainment manager, 14: airplane pilot, 15: mate, 16: truck driver, 17: mail carrier, 18: telemarketing salesman, 19: public relations assistant, 20: janitor, 21: pet hair designer, 22: sports or recreational instructor, 23: architect, 24: land surveyor, 25: matchmaker or wedding planner, 26: wall paper specialist, 27: car mechanic, 28: welding specialist, 29: network system engineer, 30 : software engineer, 31 : fishery worker.
상, 3: 교육상 말하기 하, 4: 교육상 말하기 상) 간 직업 추천 정 도 차이를 살펴보면, 말하기 요구량이 낮은 직업군들에서 교육 수준의 높고 낮음 $(1$ vs. 3)은 직업 추천에 유의한 차이를 보이 는 반면, 말하기 요구량이 높은 직업군들에서 교육 수준의 높 고 낮음(2 vs. 4)은 직업 추천에 유의한 차이를 보이지 않았다. 이와 달리 교육 수준이 동일한 조건(1 vs. 2 와 3 vs. 4)에서 말하 기 요구량의 차이는 직업 추천에 유의한 차이를 가져왔다. 결국 경도 말더듬이나 중도 말더듬 모두 직업 관련 말하기 요구량이 낮은 직업군을 상대적으로 높게 추천하는 것으로 나타났다. 또 한 말하기 요구량이 낮은 직업군에서는 교육 수준이 낮은 직업 군을 높게 추천하는 것으로 나타났다. 반면, 교육 수준에 상관 없이 말하기 요구량이 높은 직업군을 낮게 추천하는 것으로 나 타났다. Figure 4는 경도 말더듬과 중도 말더듬에 따른 평균 직 업 추천 정도를 보여주는 것이며, Table 2는 직업군 간 추천 정 도에 대한 사후검정 결과이다.

\section{직업 추천 정도와 말하기 요구량과 교육 수준 정도 간 상관관계}

4개 직업군에 속한 모든 개별 직업들의 말하기 요구량 인식 점수와 직업 추천 정도 점수의 평균값을 통해 상관관계를 분석 한 결과, 전반적으로 유의한 수준에서 부적 상관관계를 나타냈 다(rho $=-0.944, p<0.001)$. 두 실험조건에서의 상관관계를 분석한 결과 경도 말더듬 $(\mathrm{rho}=-0.912, p<0.001)$ 과 중도 말 더듬(rho $=-0.959, p<0.001)$ 모두 유의한 수준에서 부적 상 관관계가 나타났다. 또한 개별 직업들의 교육 수준 인식 점수와

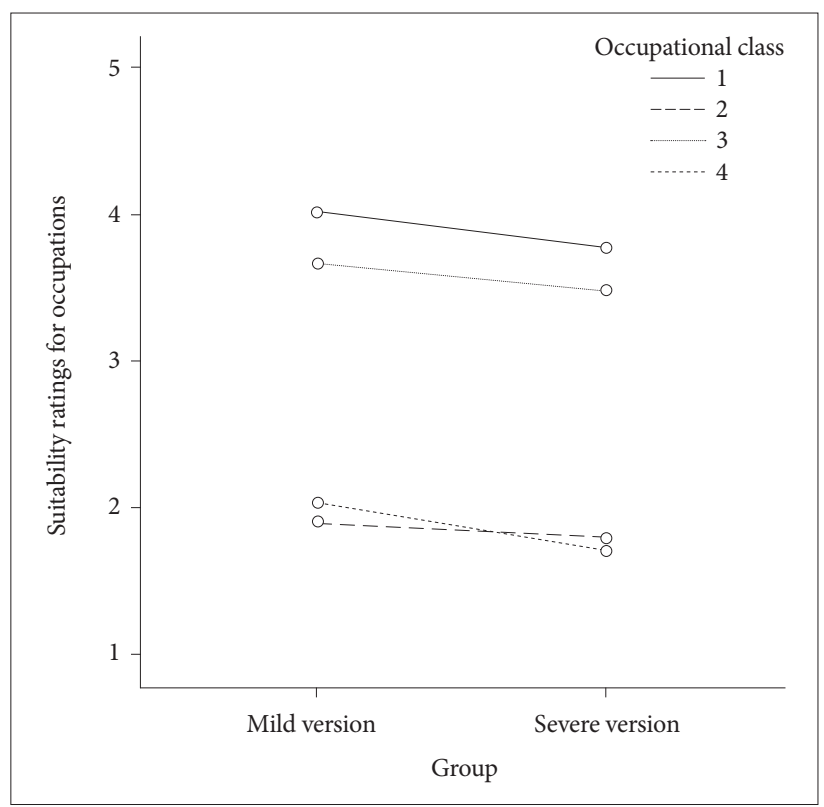

Figure 4. Mean suitability ratings for occupations in the four demand quadrants. Class 1: L Educ + L Spk, Class 2: L Educ + H Spk, Class 3: H Educ + L Spk, Class 4: H Educ + H Spk. L Educ: low educational requirements, $\mathrm{H}$ Educ: high educational requirements, $\mathrm{L}$ Spk: low speaking demands, H Spk: high speaking demands. 
Table 2. Post-hoc comparisons of occupational advice quadrant scores

\begin{tabular}{lccrrr}
\hline \multicolumn{1}{c}{ Pair } & Mean & SE & $t$ & $p$-value & Cohen's d \\
\hline L Educ L Spk (1)-L Educ H Spk (2) & 2.039 & 0.604 & 22.910 & $<0.001$ & 3.378 \\
L Educ L Spk (1)-H Educ L Spk (3) & 0.316 & 0.549 & 3.898 & $<0.001$ & 0.575 \\
L Educ L Spk (1)-H Educ H Spk (4) & 2.017 & 0.685 & 19.984 & $<0.001$ & 2.947 \\
L Educ H Spk (2)-H Educ L Spk (3) & -1.724 & 0.714 & -16.367 & $<0.001$ & -2.413 \\
L Educ H Spk (2)-H Educ H Spk (4) & -0.022 & 0.520 & -0.288 & 0.774 & -0.043 \\
H Educ L Spk (3)-H Educ H Spk (4) & 1.701 & 0.697 & 16.554 & $<0.001$ & 2.441 \\
\hline
\end{tabular}

L Educ: low educational requirements, H Educ: high educational requirements, L Spk: low speaking demands, H Spk: high speaking demands, SE: standard error

직업 추천 정도 점수의 평균값을 통해 상관관계를 분석한 결 과 전반적으로 부적 상관관계가 나타났다(rho $=-0.336, p=$ 0.011). 각 실험조건에서의 상관관계를 분석한 결과 경도 말더 듬(rho $=-0.465, p=0.008)$ 과 중도 말더듬(rho $=-0.424, p=$ 0.017)에서 모두 유의한 수준에서 상관관계를 보였다. 따라서 직업 추천에 있어 경도와 중도 말더듬 모두 말하기 요구량과 필요한 교육 수준이 전반적으로 유의한 수준에서 부적 상관관 계를 보이고 있었다. 특히 필요한 교육 수준 정도보다는 말하기 요구량 정도가 더 높은 부적 상관성을 보여주고 있었다. 이는 말더듬 성인의 경우, 말하기 요구량이 낮은 직업을 우선적으로 추천하는 것과 마찬가지 결과로 해석된다.

\section{직업 추천(준비)에 관한 직업상담사의 조언}

질문지 마지막 문항에서는 실험에 참가한 직업상담사를 대 상으로 말더듬 성인을 위해 직업 추천 또는 준비와 관련해 3 가 지 조언을 기술하도록 하였다(“말을 더듬는 사람에 대해 직업 추천 또는 준비와 관련해 조언을 해 주신다면 무엇이 있습니 까? 구체적으로 3 가지 조언을 기술해 주십시오.”). 기술된 조언 들은 모두 106가지였고, 코딩을 하여 주제별로 분류하였다. 실 험 대상자들이 기술한 조언을 질적 분석하여 코딩한 결과는 Figure 5 와 같다.

직업 추천 및 준비와 관련된 조언은 말하기 요구량이 적은 직업을 추천한 조언이 37\%(39/106)로 가장 많았다. 직업 관련 교육 수준 정도와 상관없이 말하기 요구량이 적은 직업군 추천 에 중점을 두었다. 예를 들면 연구원, 소프트웨어 개발자, 네트 워크 시스템 개발자, 도배공, 어업 관련 종사자 등이 구체적으 로 추천되었다. 또한 선정된 31개의 직업군과 정확히 일치하지 는 않아도 말을 적게 사용해도 될 것으로 추정되는 사무직, 전 문직, 기술직, 인터넷 상담사, 요리사, 예술가, 헬스케어 종사자, 비즈워크 개발자 등도 추천되었다.

그 다음은 자신감이나 대화 태도 등 언어 외적인 것이 직업 준비에 중요하다는 조언이 22\%(23/106)로 나타났다. 구체적인 조언의 사례는 다음과 같다.

· 유창성이 떨어진다 해도 진정성이 돋보인다면 문제될 것

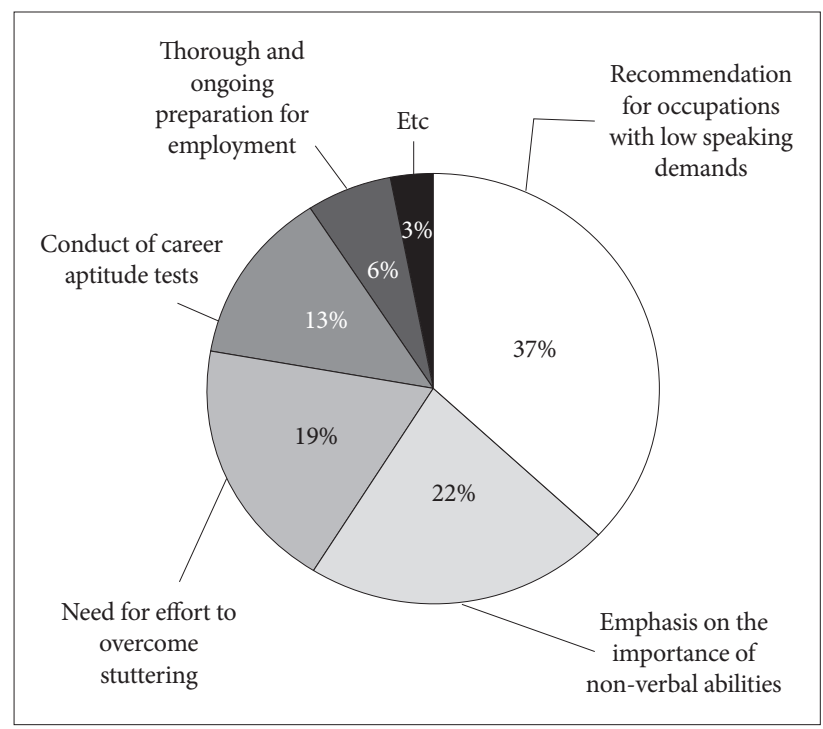

Figure 5. Occupational advice from vocational counselors for adults who stutter.

은 없다고 보여집니다. 진실된 태도로 적극적인 경청을 하신다 면, 말 잘하는 것보다 나을 것 같습니다. 완벽하고 유창한 구사 보다는 의미를 전달하는 데에 초점을 맞추는 것이 중요합니다 (연구 대상자 10번).

- 한 명이라도 조력자 또는 지지자를 확보해 도움(정서적 포 함) 받도록 하세요(연구 대상자 14번).

- 사람을 대할 때 두려워하지 말고, 시선에 신경 쓰지 말고 자신감 있게 행동하기를 바랍니다. 당신도 다른 사람에게 많은 관심이 없듯이 다른 사람도 마찬가지로 당신의 장애에 대한 시 선이 당신이 생각하고 있는 것보다는 낫기 때문입니다(연구 대 상자 16번).

- 사회생활(직업)을 할 때 사람들이 편견을 깰 수 있도록 긍 정적이면서 활발한 모습(본인이 성격에 맞는다면)을 많이 보여 주는 것이 좋겠습니다(연구 대상자 23번).

그 다음으로는 유창성 문제를 극복하는 노력이 필요하다는 조언이 19\%(20/106)로 나타났는데, 지속적인 언어치료의 필요 와 상담이나 면접 연습, 스스로 노력해야 한다는 조언들이 포 함된다. 적성검사를 통해 자신에게 맞는 직업과 자신의 장점을 
찾으라는 조언이 13\%(14/106)로 뒤를 이었다.

- 언어교정을 받을 수 있으면 치료와 상담을 받을 것을 권 유합니다(연구 대상자 11).

- 누구나 결점은 있으니 나의 결점에 집중하지 말고, 조바심 내지 말고, 장점을 활용해 할 수 있는 일을 생각해 보세요(연구 대상자 28번).

- 참여자의 흥미와 적성을 파악할 수 있는 심리검사를 진행 후, 최대한 흥미 또는 적성을 살리되 현실 가능한 범위에서 직업 선택을 할 수 있도록 격려하고 지원해야 합니다(연구 대상자 37 ).

철저하고 지속적인 취업 준비가 필요하다는 조언이 6\%(7/106) 를 차지했는데 구체적인 내용은 다음과 같다.

- 정한 직업에 맞춰 미리 면접 질문이나 희망하는 일자리에 필요한 정보를 수집한다. 최대한 연습, 노력의 시간에 초점을 둔다(연구 대상자 8번).

- 본인이 하고 싶은 일을 적극적으로 실험해 보기 위한 훈 련 찾아보기. 아르바이트나 일용직 상관없이 일 경험 쌓아보기 (연구 대상자 13번).

그 외 장애 정도에 따라, 본인의 선호에 따라 조언이 달라질 것이라는 등의 기타 의견이 $3 \%(3 / 106)$ 로 나타났다.

\section{DISCUSSIONS}

본 연구의 목적은 말더듬 성인에 대한 직업상담사의 직업 추 천에서 말더듬의 정도 차이(즉, 경도 말더듬과 중도 말더듬)가 직업 추천에 어떠한 영향을 미치는지, 직업과 관련된 말하기 요 구량(상-하)과 교육 수준 정도(상-하)에 따른 네 가지 직업군에 대한 추천 양상은 어떠한지, 그리고 말더듬 성인에게 직업 추천 과 준비를 위해 제안할 수 있는 구체적인 조언과 권고 사항은 무엇인지 알아보는 것이었다.

먼저, 본 연구에서는 말더듬에 대한 전문지식이나 상담 경험 이 없는 직업상담사를 실험 대상자로 선정하여 대부분 말더듬 성인을 처음 접하는 면접관의 입장에서 말더듬을 가진 지원자 의 취업 여부를 고려하여 말더듬 성인의 직업 추천 양상에 대 해 살펴보고자 하였다. 직업 추천에 앞서 말더듬의 중도 정도를 실제 어떻게 지각하는지 알아보기 위해 두 가지 말더듬 발화의 비유창성 빈도를 측정하도록 하였을 때, 경도 말더듬과 중도 말더듬의 비유창성 빈도가 각각 평균 16.00 회 $(\mathrm{SD}=3.503)$, 32.65회(SD = 17.701)로 실제 전문가 평가에서 측정된 15 회, 78 회와 비교하여 중도 말더듬 발화에서 큰 차이를 보였다. 이는 본 연구에서 발화 유창성을 제외한 화자의 외모나 면접 태도, 얼굴 표정, 제스처 등과 같은 시각적인 평가 요인들을 제거하기 위해 음성 샘플만을 사용한 청지각적 평가에 근거한 결과일 수 있다. 말더듬은 구어 비유창성 이외에 탈출행동과 회피행동과
같은 부수행동이 동반하여 나타날 수 있으며 특히 중도 말더듬 에서 보여지는 연장 또는 막힘의 정확한 평가는 청지각적 판단 만으로는 제한적일 수 있다. 이들 결과는 청지각적 비유창성 평 가에서 일반인이 전문가보다 말더듬의 중도 정도를 낮게 평가 한 선행연구(Amir et al., 2018)와도 일치하였다.

두 가지 말더듬 발화에서 직업 관련 말하기 요구량 및 교육 수준에 대한 인식 정도와 직업 추천 정도와의 상관관계를 살펴 본 결과, 경도 말더듬과 중도 말더듬 발화 모두에서 말하기 요 구량 및 교육 수준에 대한 인식 정도가 직업 추천 정도와 유의 한 부적 상관을 보였으며 교육 수준보다는 말하기 요구량에서 보다 높은 부적 상관을 보였다. 이러한 결과는 직업상담사가 말 더듬의 중도 정도와 관계없이 말더듬 성인의 취업에서 직업과 관련된 말하기 요구량과 교육 수준을 모두 중요한 요인으로 인 식하나 교육 수준보다는 말하기 요구량을 우선으로 고려하여 직업을 추천하고 있음을 보여준다. 이는 직업상담사가 말더듬 성인에게 말하기 요구량이 적은 직업을 추천한다는 선행연구 (Gabel et al., 2004; Hurst \& Cooper, 1983a; Hurst \& Cooper, 1983b)와 동일한 결과이며 일반인을 대상으로 말더듬 성인의 직업 추천을 조사한 Logan \& O’Connor(2012)의 연구와도 일 치하는 결과이다. 이들 결과들을 종합하면 직업상담사는 말더 듬 성인의 직업 추천에서 직업과 관련된 말하기 요구량을 교육 수준보다 핵심적인 요소로 고려하고 있음을 알 수 있다. 더불어 말하기 요구량이 낮은 직업군들에서 교육 수준의 높고 낮음이 유의한 차이가 나타나 교육 수준이 높은 직업보다 낮은 직업을 더 추천하는 결과는 말하기 능력의 결함이 이와는 다른 능력, 즉 교육적 역량 또는 수준에 대한 부정적 인식으로 확장되어 나타난 결과일 가능성도 존재한다(Betz et al., 2008; Gabel et al., 2004). 즉, 말하기 능력에 대한 부정적 인상이 교육 수준에 대한 부정적 인상으로까지 확대될 수 있다는 것이다. 직업 관련 말하기 요구량뿐 아니라 교육 수준 또한 직업 추천 정도와 부 정적인 상관관계를 보여준 결과도 동일한 맥락으로 해석될 수 있겠다. 한편, 본 연구에서 음성 샘플을 통해 직업 관련 말하기 요구량과 교육 수준에 제한하여 말더듬 성인의 직업 추천 양상 을 살펴보았으나 실제 채용 현장에서 단순히 말의 능력이나 문 제만을 고려하여 지원자의 취업 여부가 결정되는 것이 아니므 로 직업상담사는 취업에 영향을 미치는 여러 요인들을 함께 고 려하여 직업을 추천하고 있음을 분명히 하여야 하겠다. 직무 관련 근로 경험 유무, 경력 기간, 자격증 유무, 직무의 대처 능 력, 인성과 태도, 희망 직종의 특성, 성별과 연령 등 담당하는 업무에 따라 중요시되는 역량과 채용 기준이 서로 다르므로 말 더듬 성인의 직업 추천에서 직업 관련 말하기 요구량이 꼭 절대 적인 결정 요인이 아닐 수 있음을 제안한다.

본 연구에서 직업상담사들이 제공한 말더듬 성인의 직업 추 
천 및 준비를 위한 구체적인 조언과 권고 사항을 살펴보면 직업 과 관련된 교육 수준과 관계없이 말하기 요구량이 적은 직업들 을 추천하는 조언이 $37 \%$ 로 가장 높았고, 유창성 문제를 극복 하기 위한 노력을 강조하는 조언이 $19 \%$, 적성검사를 통해 자신 에게 맞는 직업을 찾으라는 조언이 $13 \%$ 로 뒤를 이었다. 이들 결 과에서도 직업 관련 말하기 요구량을 우선으로 고려하여 말의 사용이 적은 직종들을 추천하고 있으나 말더듬 성인이 자신의 어려움을 극복하기 위해 꾸준히 노력하고 자신의 장점을 최대 한 개발하여 이러한 장점들이 효과적으로 활용될 수 있는 직 종을 선택하고 준비하도록 조언하고 있다. 특히 수집된 조언들 이 경도 말더듬과 중도 말더듬의 실험조건에 따라 다소 상이할 수 있다고 기대하였으나 두 조건 모두에서 조언에 관한 비중은 위와 같은 동일한 순서로 제시되었고 이는 본 연구에서 각 실 험 대상자가 한 가지 말더듬 발화만을 들은 결과일 수 있겠다. 직업상담사들의 여러 조언들을 종합하면 말더듬 성인이 유창 성 문제를 가지고 있다고 무조건 말을 적게 하는 직업을 갖도 록 추천하기보다는 유창성 문제를 극복하기 위한 노력을 멈추 지 말고 말하기 요구량이 적은 직업군 중에서도 자신의 적성에 맞는 직업을 찾기 위해 많은 노력을 기울여야 함을 강조하고 있 다. 또한 구어 능력의 어려움 이외에 다른 문제점들에 대한 조 언들이 제시되었는데 자신감을 가질 것, 두려움을 없앨 것, 직 장에서의 원만한 대인관계를 위해 긍정적인 마인드를 가질 것, 정신적인 조력자나 지지자를 확보할 것과 같은 조언들은 말더 듬 성인이 대부분 소극적이거나 위축되어 있을 것이라는 편견 을 보여주는 결과일 수 있으나, 동시에 긍적적인 태도와 자신감 을 갖고 원만한 사회생활을 하면 말더듬은 큰 문제가 되지 않 을 수 있다는 긍정적인 조언으로도 해석 가능하다.

특히 취업 준비 및 직장생활 적응에 초점을 맞춘 언어치료 병행의 중요성을 강조한 조언들에 근거하여 말더듬 성인들의 취업 및 고용 유지를 위한 효율적인 치료 방안이 마련되어야 하 겠다. 말더듬 성인의 언어중재에 있어 취업 준비 과정에서 직면 하는 면접 상황이나 취업 이후 직장생활에서 접하는 동료들과 의 대화, 직장 내 전화 상황, 발표 및 보고 상황 등의 다양한 상 황에 대처하여 개별화된 유창성 훈련이 시도되어야 하겠다. 이 와 함께 말더듬으로 인한 공포나 두려움에서 발생하는 심리적 문제, 의사소통에 대한 부정적 태도, 말을 더듬을 상황을 회피 하는 행동 등에 대한 중재도 함께 이루어져야 하겠다. 또한 말 더듬 성인은 자신의 구어 문제에서 벗어나 자신의 적성과 능력 을 개발하고, 구직자들의 취업 기회 확대를 위해 제공되는 사회 적 지원제도에 관한 정보 수집과 활용이 적극 이루어져야 하겠 다. 이와 더불어 전통경제 사회에서 Online to Offline 융합경제 의 초연결 지능사회인 4차 산업혁명 시대가 도래하면서 기존의 직종에 다양한 변화가 일어나고 있다(Ahn \& Lee, 2016). 이에
직업상담사들은 기존에 알고 있던 직업 유형 이외에 진화되고 있는 여러 직종에 관한 구체적인 지식을 쌓아 말더듬 성인 개개 인에 맞는 직업을 찾아줄 수 있기를 희망하며, 언어재활사 또한 직업상담사와 연계하여 말더듬 성인 개개인의 적성에 맞는 최 상의 직업을 모색하고 준비시킬 수 있도록 서로 협업하는 체계 를 발달시키는 데 많은 관심과 노력을 기울여야 하겠다.

본 연구의 제한점 및 제언은 다음과 같다. 첫째, 본 연구에서 발화 유창성을 제외한 다른 평가 요인들을 배제하기 위해 음성 샘플만을 사용하였으나 이는 실제 말더듬 성인을 대표하지는 않는다. 따라서 후속연구에서 부수행동 등을 포함한 말더듬 성 인의 언어행동을 자연스럽게 접할 수 있도록 동영상을 사용하 여 직업 추천에 어떠한 변화가 있는지 살펴볼 필요가 있다. 둘 째, 본 연구에서는 직업 추천 관련 요인으로 특정 직업에 대한 말하기 요구량과 교육 수준을 제안하였으나 직업 추천에 영향 을 미치는 다른 관련 요인들(직무 숙련도, 업무 환경 등)을 추가 하여 직업 추천 양상을 살펴볼 필요가 있다. 셋째, 본 연구에서 말더듬의 중도 정도를 분류하였으나 실험 대상자는 한 가지 말 더듬 발화에만 노출되므로 후속연구에서 개별 실험 대상자에게 말더듬의 중도 정도를 달리한 발화들을 함께 제공하여 직업 추 천 양상에 차이를 보이는지 연구할 필요가 있다. 넷째, Logan \& O’Connor(2012)의 연구에서는 말더듬(인)에 대한 수년간 경 험을 가지고 있는 일반인, 즉 정상 화자가 인위적으로 말더듬 을 산출하는 방식으로 음성 샘플을 생성하여 유창한 발화와 비교하여 직업 추천 정도를 알아보았다. 본 연구에서는 일반 화 자가 아닌 말더듬 성인이 의도적 말더듬 방식으로 음성 샘플을 생성하게 하였다. 비록 실제 말더듬 성인으로부터 생성한 음성 샘플이라고 하지만 좀 더 자연스러운 방식으로 음성 샘플을 생 성하여 음성 샘플의 타당도를 높일 수 있을 것이다. 예를 들어 의도적 말더듬이 아닌 시간적 압박감을 주는 상황에서 말더듬 을 생성하게 하거나 중도 말더듬 음성 샘플을 음성 편집 프로그 램(예를 들어, Praat, computerized speech lab)을 통해 경도 형 태의 음성샘플을 생성할 수도 있을 것이다. 마지막으로, 후속연 구에서는 취업을 앞둔 말더듬 성인을 연구 대상으로 하여 본인 이 희망하거나 고려하는 직업군, 취업 준비에서의 어려움, 취업 을 위한 노력 방안 등을 조사하거나 또는 이미 취업을 한 말더듬 성인을 대상으로 취업 준비를 위한 조언, 취업 현황, 선택한 직업 에 대한 만족도, 말더듬으로 인한 직장생활의 어려움, 퇴사나 이 직에 대한 고민 등을 조사한다면 말더듬 성인의 취업에 보다 실 질적인 정보 제공과 함께 말더듬 성인을 위한 직업 상담의 기초 자료로 활용될 수 있다.

중심 단어 : 취업 준비·직업 추천·말더듬·직업상담사. 


\section{Ethical Statement}

Participants were asked to sign informed consent form after the study information was provided and the researchers were assured that the participants understood the implication of their participation in this study.

The entire procedure of this research was approved by the Institutional Review Board of Catholic Kwandong University (IRB no. CKU-20-02 0201).

\section{Acknowledgments}

The authors give thanks to all of the vocational counselors who took part in this project.

\section{Declaration of Conflicting Interests}

There are no conflict of interests.

\section{Funding} N/A

\section{Author Contributions}

All authors contributed equally to this work. J.P. designed and performed experiments and wrote the paper; H.P. analyzed data, wrote the paper, and provided critical revision; S.P. analyzed data and wrote the paper. Also, the authors discussed the results together and implications and commented on the manuscript at each stage.

\section{ORCID iDs}

Heeyoung Park Jin Park

https://orcid.org/0000-0001-6714-5843 https://orcid.org/0000-0001-8183-3829

\section{REFERENCES}

Ahn, S. H. \& Lee, M. H. (2016). Fourth industrial revolution impact: How it changes jobs. Korean Academic Society of Business Administration, 8 , 2344-2363.

Amir, O., Shapira, Y., Mick, L., \& Yaruss, J. S. (2018). The speech efficiency score (SES): A time-domain measure of speech fluency. Journal of Fluency Disorders, 58, 61-69.

Betz, I. R., Blood, G. W., \& Blood, I. M. (2008). University students' perceptions of pre-school and kindergarten children who stutter. Journal of Communication Disorders, 41(3), 259-273.

Craig, A., Blumgart, E., \& Tran, Y. (2009). The impact of stuttering on the quality of life in adults who stutter. Journal of Fluency Disorders, 34(2), 61-71.

Gabel, R. M., Blood, G. W., Tellis, G. M., \& Althouse, M. T. (2004). Measuring role entrapment of people who stutter. Journal of Fluency Disorders,
29(1), 27-49.

Gabel, R. M., Hughes, S., \& Daniels, D. (2008). Effects of stuttering severity and therapy involvement on role entrapment of people who stutter. Journal of Communication Disorders, 41(2), 146-158.

Hayhow, R., Cray, A. M., \& Enderby, P. (2002). Stammering and therapy views of people who stammer. Journal of Fluency Disorders, 27(1), 1-16; quiz 16-17.

Hurst, M. A. \& Cooper, E. B. (1983a). Vocational rehabilitation counselors' attitudes toward stuttering. Journal of Fluency Disorders, 8(1), 13-27.

Hurst, M. I. \& Cooper, E. B. (1983b). Employer attitudes toward stuttering. Journal of Fluency Disorders, 8(1), 1-12.

Jeon, H. S. \& Jeon, H. E. (2015). Characteristics of disfluency clusters in adults who stutter. Journal of Speech-Language and Hearing Disorders, 24(1), 135-144.

Kim, H. H. (1996). Proceedings on the 2nd conference in The Korean Society of Phonetic Sciences and Speech Technology semiannual: Perceptual, Acoustical, and Physiological Tools in Ataxic Dysarthria Management: A Case Report. Seoul: Yonsei University.

Klein, J. F. \& Hood, S. B. (2004). The impact of stuttering on employment opportunities and job performance. Journal of Fluency Disorders, 29(4), 255-273.

Korea Employment Information Service. (2015). Occupational Outlook Handbook. Korea Employment Information Service. Retrieved from https://www.keis.or.kr/user/extra/main\%20/2108/publication/publicationOnlyList $/ \mathrm{ssp} / \% 20$ LayOutPage.do?categoryIdx=125\&pubIdx=5191 \&column $=\&$ search $=\&$ spage $=2 \#$ totalList

Lee, S. W. (2005). Fluency Disorders. Seoul: SigmaPress.

Logan, K. J. \& O'Connor, E. M. (2012). Factors affecting occupational advice for speakers who do and do not stutter. Journal of Fluency Disorders, 37(1), 25-41.

Morgan, D. L. \& Krueger, R. A. (Trans. Sin, K., Jang, Y., Kim, Y., Lee, K., Choi, M., Kim, H., et al.) (2004). Qualitative Research Methods: Focus Group. Seoul: HyunMoon Publishing Co.

Paul, R. \& Norbury, C. F. (2007). Language Disorders from Infancy through Adolescence. (4th ed). St. Louis, MO: Mosby.

Rami, M. K., Kalinowski, J., Rastatter, M. P., Holbert, D., \& Allen, M. (2005). Choral reading with filtered speech: Effect on stuttering. Perceptual and Motor Skills, 100(2), 421-431.

Riley, G. (1994). Stuttering Severity Instrument for Adults and Children (SSI-3). (3rd ed). Austin, TX: PRO-ED.

Shim, H. S., Shin, M. J., \& Lee, E. J. (2010). Paradise Fluency Assessment II (P-FA-II). Seoul: Paradise Welfare Foundation.

Van Riper, C. (1982). The Nature of Stuttering. (2nd ed.). Englwewood Cliffs, NJ: Prentice-Hall

Yaruss, J. S. \& Quesal, R. W. (2004). Stuttering and the International Classification of Functioning, Disability, and Health (ICF): An update. Journal of Communication Disorders, 37(1), 35-52. 